\title{
ACYL AND PIGMENT LIPID COMPOSITION OF TWO CHLOROPHYLL-PROTEINS
}

\author{
by \\ ANDRÉ RAWYLER'), LANDIS E. A. HENRY' ${ }^{1,2)}$ and \\ PAUL-ANDRÉ SIEGENTHALER ${ }^{1)}$ \\ 1)Laboratoire de physiologie végétale et biochimie, Université de Neuchâtel, \\ Chantemerle 20, CH-2000 Neuchâtel \\ 2)Department of Physiology, Carlsberg Laboratory, \\ Gamle Carlsberg Vej 10, DK-2500 Copenhagen Valby
}

Keywords: Spinach thylakoids, chlorophyll-proteins, acyl lipids, pigment lipids

A differential distribution of acyl and pigment lipids among chlorophyll-proteins of spinach, obtained by SDSpolyacrylamide gel electrophoresis of solubilized thylakoids, was demonstrated by thin-layer chromatography. Light-harvesting chlorophyll $a / b$-protein 2 and $P-700$ chlorophyll $a$-protein 1 were isolated and analysed for their lipid class composition including the fatty acid distribution within each lipid class. The light-harvesting chlorophyll $a / b$-protein 2 was rich in galactolipids and phosphatidylglycerol containing a high amount of 3-trans-hexadecenoic acid. In contrast, the $P-700$ chlorophyll $a$-protein I lacked these two lipid classes but was associated with sulfoquinovosyldiglyceride and phosphatidylinositol containing a comparatively large proportion of saturated fatty acids. $\beta$-carotene was preferentially associated with the chlorophyll $a$-protein whereas xanthophylls were restricted to the chlorophyll $a / b$-proteins. The present data support lateral heterogeneity in the distribution of pigment and acyl lipids within the photosynthetic lamellae.

\section{INTRODUCTION}

The chlorophyll-proteins obtained by fractionation of thylakoids solubilized in detergents have been extensively studied $(2,4,10,15,18)$, but the amount and composition of acyl lipids associated with the individual chlorophyll-proteins is unknown. Acyl lipids are prominent membrane constituents involved in the molecular organization of the membrane as well as in the activity of certain membrane-bound enzymes

Abbreviations: $\mathrm{Chl}=$ chlorophyll; $\mathrm{Chl}-\mathrm{P}=$ chlorophyll-protein; $\mathrm{Cl}_{2} \mathrm{Ind}=2,6$-dichlorophenol-indophenol; $\mathrm{NADP}^{+}=$nicotinamide adenine dinucleotide phosphate; PS = photosystem; $\mathrm{SDS} \cdot \mathrm{PAGE}=$ sodium dodecyl sulfate polyacrylamide gel electrophoresis. 
$(13,26)$. Two chlorophyll-proteins, namely the $P-700$ chlorophyll $a$-protein 1 and the lightharvesting chlorophyll $a / b$-protein 2 were prepared from spinach leaves and analysed for their content of acyl and pigment lipids.

\section{MATERIALS AND METHODS}

\subsection{Plant Material}

Spinacia oleracea (var. Nobel) was grown in a growth chamber in hydroponic culture for 14 weeks at approx. $20^{\circ} \mathrm{C}$ and a relative humidity of $70-90 \%$. A photoperiod of 10 hours light (6000 lux) and 14 hours dark was used (20).

\subsection{Analyses of chlorophyll-proteins prepared by electrophoresis}

Isolation of chloroplasts and of thylakoids showing little or no evidence of lipid hydrolysis and/or transformations was performed as described earlier (10). The thylakoids were solubilized with $1 \%$ SDS, $2 \%$ Triton X-100 (SDS/ chlorophyll ratio $10: 1 \mathrm{w} / \mathrm{w}$ ) without prior lipid extraction. Electrophoretic separation of the chlorophyll-proteins was carried out at $4{ }^{\circ} \mathrm{C}$ in the dark using a $2.4 \%$ stacking and $8 \%$ analysing gel. After separation, the gels were immediately sectioned and the individual chlorophyll-proteins electrophoretically eluted into dialysis tubing. SDS was removed by precipitation with $\mathrm{CaCl}_{2}$. Aliquots were separated by thin-layer chromatography on silica plates with hexane/acetone $(60: 40, \mathrm{v} / \mathrm{v})$ as solvent. After separation the plate was sprayed with $\mathrm{H}_{2} \mathrm{SO}_{4}$ :ethanol: $\mathrm{H}_{2} \mathrm{O}(34 / 33 / 33)$ and charred to reveal the acyl lipids.

\subsection{Isolation of chlorophyll-proteins}

Light-harvesting chlorophyll $a / b$-protein 2 was prepared as in (8) and the $P-700$ chlorophyll $a$-protein was obtained by hydroxyapatite column chromatography of Triton X-100 solubilized membranes as described by WilliamsSMITH et al. (27). The preparations could be stored in liquid $\mathrm{N}_{2}(77 \mathrm{~K})$ without any noticeable effect upon the subsequent analyses.

\subsection{Photochemical measurements}

Electron flow reactions involving $\mathrm{H}_{2} \mathrm{O} \rightarrow$ $\mathrm{Cl}_{2}$ Ind (PSII), Ascorbate $/ \mathrm{Cl}_{2}$ Ind $\rightarrow \mathrm{NADP}+$ (PSI) and $\mathrm{H}_{2} \mathrm{O} \rightarrow \mathrm{NADP}+(\mathrm{PSII}+\mathrm{PSI})$ were carried out as in (10).

\subsection{Lipid analyses}

Light-harvesting chlorophyll $a / b$-protein 2 (equivalent to $8.5 \mathrm{mg}$ total chlorophyll) was extracted twice with chloroform/methanol according to BLIGH and DYER (6) and finally with n-butanol. All organic fractions were pooled, brought to dryness under a $\mathrm{N}_{2}$ atmosphere and redissolved in a small volume of chloroform. The $P-700$ chlorophyll $a$-protein 1 (equivalent to $2.5 \mathrm{mg}$ chlorophyll) was first treated with BioBeads (Bio-Rad, Richmond, Calif.) to remove most of the Triton X-100 (12) and then extracted three times with chloroform/methanol as in (6). The organic phases were pooled, brought to dryness and redissolved in a small volume of chloroform.

Lipids of the light-harvesting chlorophyll $a / b$ protein 2 were applied to a 70-325 mesh silicic acid column $(4 \times 1 \mathrm{~cm})$ and sequentially eluted with $35 \mathrm{ml}$ chloroform (fraction A, pigments) and $50 \mathrm{ml}$ methanol (fraction B, acyl lipids). The entire lipid extract of the $P-700$ chlorophyll $a$-protein 1 was separated on a silica plate (Merck, Darmstadt, W. Germany) with chloroform $/$ methanol $/ \mathrm{H}_{2} \mathrm{O}(65: 25: 4, \mathrm{v} / \mathrm{v})$ as solvent. Fraction $\mathrm{B}$ was also separated on a silica plate with chloroform/methanol/acetic acid $/ \mathrm{H}_{2} \mathrm{O}$ $(85: 15: 10: 3, \mathrm{v} / \mathrm{v})$ as solvent. The lipid bands were visualized on the plates with an alkaline bromothymol blue spray reagent (16), isolated

Figure 1. Analyses of acyl and pigment lipids in different chlorophyll-proteins.

The chlorophyll-proteins were separated by SDSPAGE (A) and the lipids associated with each pigmented band were analyzed by thin-layer chromatography. The pigment lipids are shown in (B) and acyl lipids after charring in (C). Lipid bands are: 0 (origin) $=$ acyl lipids; $1=$ acyl-monogalactolipid; 2 $=$ neoxanthin; $3=$ violaxanthin; $4=$ sterols; $5=$ lutein; $6=$ chlorophyll $\mathrm{b} ; 7=$ chlorophyll $\mathrm{a} ; 8,9=$ phaeophytins; $10=$ unidentified carotenoid; $11=$ $\beta$-carotene. 


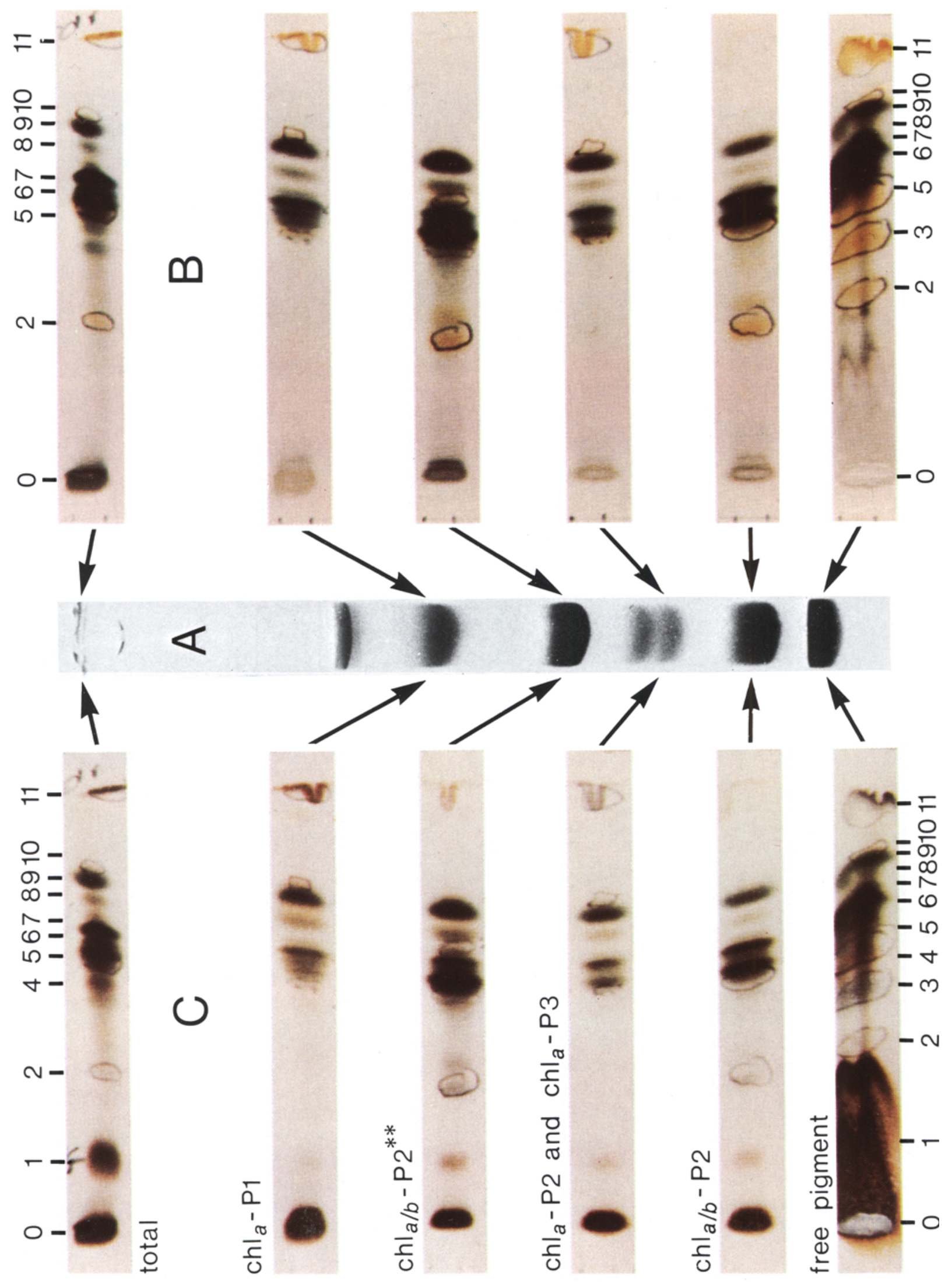


and derivatized by methylation. The fatty acid methyl esters thus obtained were analysed by gas-liquid chromatography (16).

\subsection{Pigment analyses}

\subsubsection{Carotenoid composition}

Aliquots of fraction A (see section 2.5), or aliquots of the $P-700$ chlorophyll $a$-protein 1 lipid extract were saponified (5) and the nonsaponifiable fractions separated by thin-layer chromatography with dichloromethane/ethyl acetate $(80: 20, \mathrm{v} / \mathrm{v})$ as developing solvent. The individual carotenoid bands were scraped into tubes fitted with teflon-lined stoppers and extracted with suitable volumes of diethylether to permit spectral characterization. Quantitative determinations of carotenoids were carried out using the principal peak of each spectrum and assuming an average $E_{1 \mathrm{~cm}}^{1 \%}$ of 2500 (14).

\subsection{2. $P-700$ determination}

$P-700$ was determined from the ascorbate versus ferricyanide difference spectrum $(650$ $720 \mathrm{~nm}$ ) using a molar extinction coefficient for $P-700$ of 64,000 (11).

\subsubsection{Chlorophyll determination}

Chlorophylls were determined in $80 \%$ acetone and quantified according to ARNON (3).

\section{RESULTS}

\subsection{Analyses of chlorophyll-proteins prepared by electrophoresis}

Detergent-solubilized thylakoids were electrophoretically resolved into seven pigmented bands (Figure 1A) which have been designated according to MACHOLD et al. (15). Figure 1B shows the differential distribution of major carotenoids among these pigmented bands. $\beta$ carotene is preferentially associated with $\mathrm{Chl}_{a}-\mathrm{Pl}$ and $\mathrm{Chl}_{a}-\mathrm{P} 2$, whereas violaxanthin and neoxanthin are exclusively present in the chlorophyll $a / b$-proteins. Lutein is associated with all chlorophyll-proteins. All four major carotenoids were observed in the free pigment band. The same thin-layer chromatographic plate is also shown after charring to reveal acyl lipids in
Figure 1C. Acyl lipids are associated with all chlorophyll-proteins and the free pigment band. With the solvent system used acyl-monogalactosyldiglyceride migrated ahead of the more polar lipids found close to the origin. The chlorophyll $a$-protein 1 is deficient in acyl-monogalactosyldiglyceride.

\subsection{Analyses of isolated chlorophyll-proteins}

The light-harvesting chlorophyll $a / b$-protein prepared by phase partitioning had a chlorophyll $a / b$ ratio of about 1.3 . The red absorption maximum of chlorophyll $a$ was at $675 \mathrm{~nm}$ with a shoulder at $652 \mathrm{~nm}$ and Soret peaks were found at 436 and $470 \mathrm{~nm}$. The preparation was inactive in all photochemical measurements.

The $P-700$ chlorophyll a-protein prepared by hydroxyapatite column chromatography migrated as a single pigmented band in SDS-PAGE with a mobility higher than the corresponding $\mathrm{Chl}_{a}-\mathrm{Pl}$ band. Like the $\mathrm{Chl}_{a}-\mathrm{Pl}$ band it had a chlorophyll $a / b$ ratio greater than 7 . The red absorption maximum of chlorophyll $a$ was found at $674-675 \mathrm{~nm}$ with a Soret peak at 436 $\mathrm{nm}$, whereas chlorophyll $b$ was judged absent by the lack of the characteristic absorbance at 652 and $470 \mathrm{~nm}$. The chlorophyll $/ P-700$ ratio was about 100 , and the preparation was photochemically active in photoreduction of NADP ${ }^{+}$using ascorbate- $\mathrm{Cl}_{2}$ Ind as electron donor (Table I). Additions of ferredoxin-NADP ${ }^{+}$-reductase and / or plastocyanin stimulated this activity. No PSII mediated electron flow could be measured using either $\mathrm{H}_{2} \mathrm{O}$ or 1,5-diphenylcarbazide as electron donors.

Table II shows the carotenoid composition of the $P-700$ chlorophyll $a$-protein and the lightharvesting chlorophyll $a / b$-protein. In agreement with the qualitative analysis (3.1) $\beta$ carotene is the prominent carotenoid in chlorophyll $a$-protein 1 while violaxanthin and neoxanthin are exclusively found in the chlorophyll $a / b$ proteins. Lutein was in this analysis only present in the chlorophyll $a / b$-protein. The absence of xanthophylls from the $\mathrm{Chl}_{a}-\mathrm{Pl}$ could reflect either that these pigments are not bound to this protein in vivo or their preferential extraction during isolation. Loss of carotenoids from the light harvesting $\mathrm{Chl}_{a / b}-\mathrm{P} 2$ may explain the high ratios of chlorophyll to carotenoids in this protein. 
Table I.

Electron transport activity of $P-700$ chlorophyll $a$-protein obtained after hydroxyapatite column chromatography.

Conditions

$\mu$ moles NADP + reduced $\mathrm{mg} \mathrm{chl} \mathrm{C}^{-1} \mathrm{~h}^{-1}$

1. Basic medium

2. Basic medium + ferredoxin-NADP +-reductase

3. Basic medium + plastocyanin

4. Basic medium + ferredoxin/NADP + reductase and plastocyanin

\subsection{Acyl lipid composition of the isolated chlorophyll-proteins}

The lipid class and fatty acid composition of the isolated light-harvesting chlorophyll $a / b$ protein and of the chlorophyll $a$-protein 1 is presented in Tables III and IV, respectively. While the $\mathrm{Chl}_{a / b}-\mathrm{P}$ contained galactolipids and four ionic lipid classes the $\mathrm{Chl}_{a}-\mathrm{P} 1$ yielded only sulfoquinovosyldiglyceride and phosphatidylinositol. Comparing the fatty acid composition of phosphatidylinositol from both proteins a large difference in the degree of saturation is noticeable. The phosphatidylinositol from $\mathrm{Chl}_{a / b}-\mathrm{P}$ contains $46 \%$ linolenic acid [18:3] while that of $\mathrm{Chl}_{a}-\mathrm{Pl}$ has only $6 \%$ of this polyunsaturated fatty acid. A similar tendency of greater saturation of the fatty acids in the $\mathrm{Chl}_{a}-\mathrm{Pl}$ is apparent for the sulfoquinovosyldiglyceride.

Besides the dominating content of monogalactosyldiglyceride and digalactosyldiglyceride, the $\mathrm{Chl}_{a / b}$-P contains as a major component phosphatidylglycerol with a high content of 3-transhexadecenoic acid [16:1(3t)] (Table III). Comparing the content of ionic lipids in the $\mathrm{Chl}_{a / b}-\mathrm{P}$ preparation with that of the thylakoids (17) a $20 \%$ enrichment is observed. This is attributable to a 2-fold increase in phosphatidylglycerol and a 3-fold increase in sulfoquinovosyldiglyceride in the preparation of $\mathrm{Chl}_{a / b}$-P. The ratio of galactolipids to chlorophyll is lower in the isolated $\mathrm{Chl}_{a / b}-\mathrm{P}$ than in total thylakoids. The presence of lyso-derivatives (lyso-acyl-monogalactosyldiglyceride, lyso-phosphatidylcholine and lyso-phosphatidylinositol) appears to be a result of aging as their relative amounts in thylakoids are dependent upon the physiological state of the preparation (22).

\section{DISCUSSION}

Lipids detected in isolated chlorophyll-proteins were earlier considered to originate from artifactual exchange processes involving the detergent and membrane lipids (23). The reproducibility of the differential acyl lipid and carotenoid composition among the isolated chlorophyll-proteins indicates specific associations.

The proposal of ANDERSON (1) that the light-

Table II.

Comparison of the molar ratios of chlorophyll to carotenoid in two isolated chlorophyll-proteins with the ratios in thylakoids.

\begin{tabular}{lccc}
\hline & Thylakoids (19) & $\begin{array}{c}\text { Light-harvesting } \\
\text { chlorophyll } a / b \text {-protein }\end{array}$ & $\begin{array}{c}P \text {-700 chlorophyll } \\
a \text {-protein }\end{array}$ \\
\hline$\beta$-carotene & 8 & 200 & 10 \\
Lutein & 7 & 48 & $\infty$ \\
Violaxanthin & 9 & 333 & $\infty$ \\
Neoxanthin & 14 & 1000 & $\infty$ \\
\hline
\end{tabular}


A. RAwYLER et al.: Lipids of chlorophyll-proteins

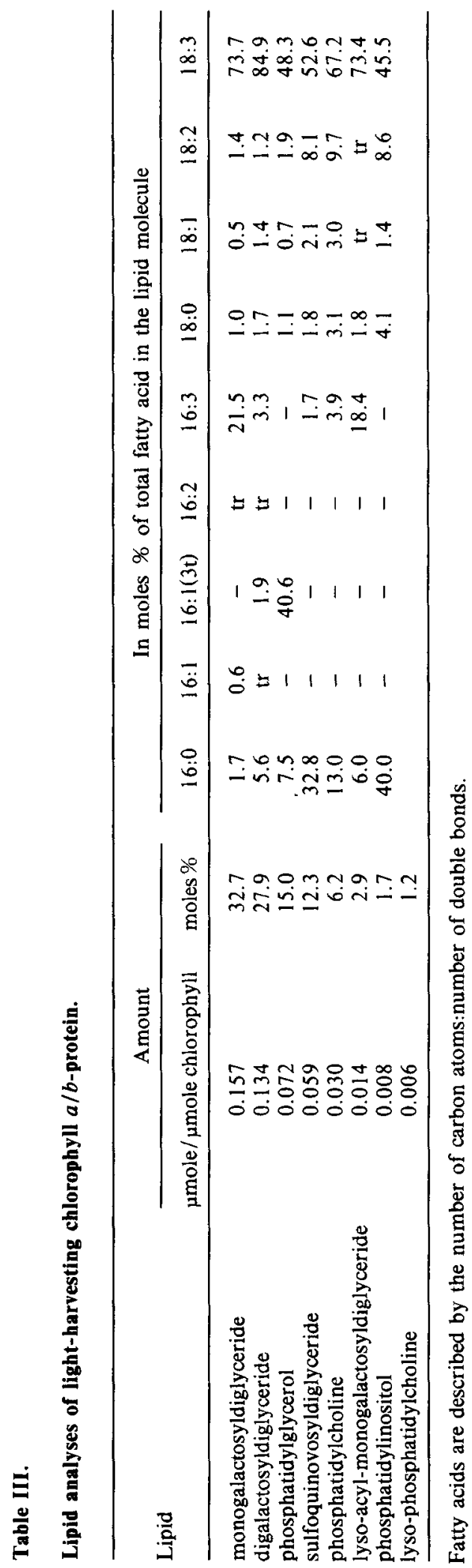


Table IV

Lipid analyses of $P-700$ chlorophyll a-protein.

\begin{tabular}{lcccccccc}
\hline \multirow{2}{*}{ Lipids } & \multicolumn{6}{c}{ In moles \% of total fatty acid in the lipid molecule } \\
\cline { 2 - 8 } & & $16: 0$ & $16: 1$ & $16: 1(3 \mathrm{t})$ & $18: 0$ & $18: 1$ & $18: 2$ & $18: 3$ \\
\hline sulfoquinovosyldiglyceride & $34.5^{*}$ & 16.5 & 0.4 & 0.2 & 10.0 & 4.0 & 5.0 & 32.0 \\
& $72.2^{+}$ & 23.6 & 0.5 & 0.4 & 15.6 & 6.5 & 7.9 & 45.5 \\
phosphatidylinositol & $13.3^{*}$ & 9.6 & - & - & 12.2 & 1.5 & 1.6 & 1.5 \\
& $27.8^{+}$ & 36.3 & - & - & 45.9 & 5.8 & 6.1 & 5.8 \\
\hline
\end{tabular}

Sometimes traces of phosphatidylcholine and lyso-phosphatidylinositol were detected.

$*$ = nanomoles lipid $/ \mu$ mole chl.

$+=$ moles $\%$

Fatty acids are described by the number of carbon atoms:number of double bonds.

harvesting chlorophyll $a / b$-protein participates in membrane stacking and that anionic lipids are mediators in this process is in agreement with the high content of phosphatidylglycerol and sulfoquinovosyldiglyceride in light-harvesting chlorophyll $a / b$-protein.

TUQUET (24) has reported the disorganization of the grana stacks upon treatment with snake venom phospholipase $A_{2}$, which specifically hydrolyses phosphatidylcholine and phosphatidylglycerol. Phosphatidylglycerol molecules esterified at the C-2 position of the glycerol with 3-trans-hexadecenoic acid were found preferentially associated with the light-harvesting chlorophyll $a / b$-protein (7). Phosphatidylglycerol molecules containing the 3-trans-hexadecenoic acid have also been implicated in the formation of appressed regions in chloroplasts $(9,25)$. The present lipid analyses of the $\mathrm{Chl}_{a / b}-\mathrm{P} 2$ conform to these observations.

The strongly polar lipids with a high content of saturated fatty acids ( $40 \%$ in sulfoquinovosyldiglyceride and $82 \%$ in phosphatidylinositol) in the $P-700$ chlorophyll $a$-protein were not removed even after extensive treatment with $0.5 \%$ Triton X-100. This may be due to polar electrostatic interactions between the sulfoquinovosyl and phosphoryl-inositol head groups and certain polar amino acid residues in the protein moiety, together with hydrophobic interactions between the acyl chains and non-polar amino acid residues. The phosphatidylinositol and sulfoquinovosyldiglyceride molecules associated with the $P-700$ chlorophyll $a$-protein could not be hydro- lysed by phospholipase $A_{2}$, by Rhizopus arrhizus lipase or by potato lipolytic acyl hydrolase suggesting the unavailability of these lipids to the enzymes. The strong resistance of photosystem I electron transport towards aging in vitro, compared to that of photosystem II (21) may be related to this strong lipid-protein interaction. The organization of these acyl lipids in a boundary layer around the protein core seems unlikely from their low molar ratios (chlorophyll/sulfolipid/phosphatidylinositol 1000:35:13) (cf. 1).

\section{ACKNOWLEDGEMENTS}

The authors wish to thank Professor DiTER voN Wettstein and Drs. Birger Lindberg Møller and Jørn DalgaArd Mikkelsen for their useful assistance, comments and criticism during the preparation of the manuscript. In addition, the technical assistance of Mss. GARANCE Ducommum, Lena Kongsrud and AnN-SofI StEINHOLtz is gratefully acknowledged. Financial support was provided by the Swiss National Science Foundation (Grant 3.661.080 to PAS), the Emil-Barrell Foundation, F. HoffmannLaRoche AG (Switzerland) and by the European Molecular Biological Organization (EMBO).

\section{REFERENCES}

1. ANDERson, J. M.: The molecular organization of chloroplast thylakoids. Biochim. Biophys. Acta. 416, 191-235 (1975) 
2. Anderson, J. M., J. C. Waldron \& S. W. THORNE: Chlorophyll-protein complexes of spinach and barley thylakoids. FEBS Lett. 92, 227233 (1978)

3. Arnon, D. I.: Copper proteins in isolated chloroplasts. Polyphenoloxidase in Beta vulgaris. Plant Physiol. 24, 1-14 (1949)

4. Bar-Nun, S., R. Schantz \& I. Ohad: Appearance and composition of chlorophyll-protein complexes I and II during chloroplast membrane biogenesis in Chlamydomonas reinhardi. $y-1$ Biochim. Biophys. Acta. 546, 84-92 (1977)

5. Barret, J. \& J. M. Anderson: The $P-700$ chlorophyll a-protein complex and two major light-harvesting complexes of Acrocarpia paniculata and other brown seaweeds. Biochim. Biophys. Acta. 590, 309-323 (1980)

6. Bugh, E. G. \& W. J. Dyer: A rapid method of total lipid extraction and purification. Can. J. Biochem. 37, 911-917 (1959)

7. Duval, J. C., J. P. Dubace \& A. Trémolières: An hypothetic role of phosphatidylglycerol and 3-trans-hexadecenoic acid in the light reactions of the photosynthetic process. In: Biogenesis and function of plant lipids (P. Mazliak, P. Benveniste, C. Costes \& P. Douce, eds.). Elsevier/ North Holland, Biomedical Press. pp. 91-94 (1980)

8. Foyer, C. H. \& D. O. Hall: Superoxide dismutase activity in the functioning chloroplast. In: clinical and biomedical aspects of superoxide and superoxide dismutase. Developments in Biochemistry Ila (J. V. Bannister \& H. A. O. Hill, eds.) Elsevier/North Holland. pp. 380-389 (1980)

9. Guillot-Salomon, T., A. Trémolières, C. Tuquet \& J. P. DubacQ: Trans-3-hexadecenoic acid and grana stacking. In: Biogenesis and function of plant lipids (P. Mazliak, P. Benveniste, C. Costes \& R. Douce, eds.) Elsevier/ North Holland Biomedical Press 95-98 (1980)

10. Henry, L. E. A. \& P. A. Siegenthaler: Does the initial state of thylakoids influence photochemical activities, lipid transformations and the characteristics of the chlorophyll-protein complexes? Proceedings of the 5 th Internat. Congress Photosynthesis (Halkidiki, Greece) in press (1981)

11. Hiyama, T. \& B. Ke: Difference spectra and extinction coefficients of $P-700$. Biochim. Biophys. Acta. 262, 160-171 (1972)

12. Holloway, P. W.: A simple procedure for removal of Triton X-100 from protein samples. Anal. Biochim. 53, 304-308 (1973)

13. Jost, P. C., O. H. Griffith, R. A. Capaldi \& G. VANDERKOOI: Evidence for boundary lipid in membrane. Proc. Natl. Acad. Sci. 70, 480-484 (1973)

14. LiaAne-Jensen, S. \& A. Jensen: Quantitative determination of carotenoids in photosynthetic tissues. Methods Enzymol. 23A, 586-602 (1971)

15. Machold, O., D. J. Simpson \& B. L. Møller: Chlorophyll-proteins of thylakoids from wildtype and mutants of barley (Hordeum vulgare L.) Carlsberg Res. Commun. 44, 235-254 (1979)

16. Rawyler, A. \& P. A. Siegenthaler: Rapid analyses of membrane lipids using a combination of thin-layer chromatography and scanning of photographic negatives. J. Biochem. Biophys. Methods 2, 271-281 (1980)

17. Rawyler, A. \& P. A. Siegenthaler: Role of lipids in functions of photosynthetic membranes as revealed by treatment with lipolytic acy! hydrolase. Eur. J. Biochem. 110, 179-187 (1980)

18. SАтон, K.: Polypeptide composition of the purified photosystem II pigment-protein complex from spinach. Biochim. Biophys. Acta. 546, 84-92 (1979)

19. Sieferman-Harms, D.: The role of carotenoids in chloroplasts of higher plants. In: Biogenesis and Function of Plant Lipids (P. Mazliak, P. Benveniste, C. Costes \& R. Douce, eds.) Elsevier/North Holland Biomedical Press, pp. $331-340(1980)$

20. Siegenthaler, P. A. \& F. Depéry: Influence of unsaturated fatty acids on chloroplasts. Eur. J. Biochem. 61, 573-580 (1976)

21. Siegenthaler, P. A. \& A. Rawyler: Aging of the photosynthetic apparatus. Change in $\mathrm{pH}$ dependence of electron transport and relationships to endogenous free fatty acids. Plant Sci. Lett. 9, 265-273 (1977)

22. Siegenthaler, P. A., A. Rawyler \& L. E. A. HeNRY: A new type of correlation between changes in lipid composition and loss of electron transport activity during aging in vitro. Proceedings of the 5th Int. Cong. Photosynthesis (Halkidiki, Greece) in press (1981)

23. THORnBer, J. P.: Chlorophyll-proteins: Lightharvesting and reaction center components of plants. Ann. Rev. Plant Physiol. 26, 127-158 (1975)

24. Tuquer, C.: Modifications de l'ultrastructure des chloroplastes isolés de l'épinard sous l'action de la phospholipase A. C. R. Acad. Sc. Paris 274, 1473-1476 (1972)

25. Tuquet, C., T. Gulllot-Salomon, M. de Lubac \& M. Signol: Granum formation and the presence of phosphatidylglycerol containing 
A. RAWYLER et al.: Lipids of chlorophyll-proteins

trans- $\triangle$ 3-hexadecenoic acid. Plant Sci. Lett. 8, 59-64 (1977)

26. Warren, G. B., M. D. Houslay, J. C. Metcalfe \& N. J. M. Birdsall: Cholesterol is excluded from the phospholipid annulus surrounding an active calcium protein. Nature (Lond.) 255, 684687 (1975)
27. Williams-Smith, D. L., P. Heathcote, C. K. SiHRa \& M. C. W. Evans: Quantitative electron paramagnetic resonance measurements of the electron-transfer components of the photosystem I reaction centre. Biochem. J. 170, 365-371 (1978) 